\title{
Open Innovation in Eastern Europe and Central Asia
}

\author{
Bernd Ebersberger $^{1} \&$ Nils Mevenkamp ${ }^{1}$ \\ ${ }^{1}$ Management Center Innsbruck, Innsbruck, Austria \\ Correspondence: Bernd Ebersberger, Management Center Innsbruck, Innsbruck, Austria, Tel: 43-512-2070-1810. \\ E-mail: bernd.ebersberger@mci.edu
}

Received: April 27, 2016

Accepted: May 13, 2016

Online Published: June 1, 2016

doi:10.5430/jbar.v5n2p8

URL: http://dx.doi.org/10.5430/jbar.v5n2p8

\begin{abstract}
Innovation has been regarded as the crucial driving force for competitiveness. Recently, new approaches to innovation have transformed the innovation activities of firms. Open innovation, for instance, has emphasized the role of external partners in increasing innovation performance and competitiveness. In this analysis we link the implementation of open innovation practices to the competitive environment of the firm. We use a comprehensive firm level dataset for firms in 30 countries in Eastern Europe and Central Asia. We find that innovation activities are significantly affected by the competitive environment of the firm. The competitive intensity exerts an inverse u-shaped effect on innovation activities. For the implementation of open innovation practices we do not find significant effects exerted by the competitive environment. Rather, we see that it is international ownership linkages that facilitate the diffusion and implementation of open innovation practices in firms in Eastern Europe and Central Asia.
\end{abstract}

Keywords: Open innovation, Innovation, Competition, Eastern Europe, Central Asia

\section{Introduction}

Starting with Schumpeter (e.g. Schumpeter, 1942) scholars have argued that innovation is the most important source of firm competitiveness and societal welfare (Baumol, 2002). In a broad Schumpeterian sense innovation encompasses the introduction of new products (goods and services), implementation of new production processes, and what we would now describe as marketing innovation and organizational innovation. This taxonomy has been extensively used to analyze innovation and its positive effects on different dimensions of firm level competitiveness (Geroski, Machin, \& Van Reenen, 1993; Love, Roper, \& Du 2009; Cefis \& Ciccarelli, 2005), regardless of how firm internal processes create, produce, and diffuse innovation.

In 2003 'open innovation' was introduced by Chesbrough (2003) as a normative strategic concept to increase innovation performance, where open innovation refers to an innovation model that - from a firm's point of view reflects an open system architecture. Narrative evidence about the value of open innovation, referencing amongst others Procter \& Gamble's seminal 'Connect \& Develop' initiative (Huston \& Sakkab, 2006) or the convincing story of Quilts of Denmark (Vanhaverbeke, 2011), have indicated that open innovation delivers a superior innovation performance. Scholars have also generated quantitative evidence to substantiate the claim that innovation performance of firms can be increased by opening up the innovation process (Ebersberger, Bloch, Herstad, \& Van De Velde, 2012; Ebersberger, Herstad, Iversen, Kirner, \& Som, 2011; Ebersberger \& Herstad, 2011; Grimpe \& Kaiser, 2010; Köhler, Sofka, \& Grimpe, 2012; Laursen \& Salter, 2006; Leiponen \& Helfat, 2010; Love, Roper, \& Bryson, 2011).

With few exceptions only little attention has been put on the question which factors affect the adoption of open innovation practices of firms in the first place (Ebersberger et al., 2011).

In this paper we investigate factors that affect firm's adoption of inbound open innovation practices. In our analysis we focus on the role of competition to drive innovation activities and open innovation in particular for firms in Eastern Europe and Central Asia, a geographical region that has attracted very little attention, although the region encompasses about 480 million consumers.

We use a firm level survey created by the World Bank and the European Bank for Reconstruction and Development which supplies detailed information on 15884 firms in 30 countries in Eastern Europe and Central Asia (World Bank \& European Bank for Reconstruction and Development, 2015). In the next section we introduce the innovation 
system as a conceptual framework which embeds firms through their open innovation strategies. Then we present the data, the empirical analysis and finally discuss the findings.

\section{Literature Review \& Hypotheses}

As already mentioned above, since the early 1900s innovation has been regarded as an important - if not the most important - determinant of firm competitiveness (Schumpeter, 1942), of growth and of societal welfare (Baumol, 2002). Since the mid of the 1980 s the perception of the innovation process has changed profoundly. No longer can the innovation process be interpreted as a linear process sequentially linking research, development, production and marketing but it has to be conceived as a process with multiple feedback loops, with various interactions between different corporate functions and with the knowledge generation through research as a key function linking different stages of the process on the firm level (Kline \& Rosenberg, 1986).

On the level of the economy the growing frustration with the linear innovation process and the insights generated by the evolutionary theory of the firm (Nelson \& Winter, 1982) policy makers and scholars turned to a new framework to conceive economy-wide innovation processes. the innovation system emphasizes that it is not the corporate firm alone that creates and diffuses innovation, rather it is a heterogeneous set of actors such as firms, research organizations, higher education institutions, government bodies, etc. that are involved in the innovation process (Edquist, 2005). These actors are connected by a multitude of ties and interactions, exchanging knowledge, competencies, and artifacts. Jointly they facilitate the development, diffusion and utilization of new technologies and innovation (Freeman, 1987, 1988; Lundvall, 1988, 1992; Nelson, 1988, 1993). Depending on the demarcation identifying which actors belong to the system and which ones do not the literature distinguishes territorial (i.e. national or regional) innovation systems (Cooke, Gomez Uranga, \& Etxebarria, 1997; Freeman, 1987; Lundvall, 1992; Nelson, 1993), technological innovation systems (Callon, 1992; Carlsson, 1995) and sectoral innovation systems (Malerba, 2002). Overall the innovation system concept provides a new policy perspective (Borrás \& Edquist, 2013) on innovation activities which has been heavily utilized since its first introduction into national innovation policy in Finland (Lemola, 2002). The innovation system concept also helps to explain differences in innovation performance of territorial systems (Fritsch \& Slavtchev, 2011) and provides the basis for a systemic line of reasoning in innovation increasingly used in social sciences, economics and management (Blättel-Mink \& Ebner, 2009).

From a micro perspective of the individual firm the resources based view highlights that firm's competitiveness strongly depends on a firm's access to resources and capabilities that are not equally distributed across firms (Peteraf, 1993; Wernerfelt, 1984). The knowledge based view of the firm stresses that knowledge is the most important resource (Grant, 1996). The firm's competitiveness strongly hinges on the firm's ability to combine and recombine old and new knowledge to create innovation. However, firms realize that they lack the capacity to keep abreast all relevant bits and pieces of knowledge that could be relevant for their innovation activities. They lack the internal capacity to generate all the required knowledge internally required to exploit all opportunities that present themselves. Firms even lack the capacity to exploit all opportunities that might be valuable for the firm. Given that, it is clear that the competitiveness of firms strongly hinges on the firm's ability to compose, establish and maintain both internal processes of knowledge creation and external processes of knowledge acquisition (Nicholls-Nixon \& Woo, 2003).

The internal processes of knowledge generation are typically the formalized and systematic R\&D activities and the less formalized, experience based processes of knowledge creation through doing, using, and interacting (DUI), which are usually combined (Jensen, Johnson, Lorenz, \& Lundvall, 2007). The external processes of knowledge acquisition can be interpreted as the micro, firm-level basis for the interactions in the innovation system (Graf, 2010). External knowledge exchange activities comprise of recruiting (Boschma, Eriksson, \& Lindgren, 2009; Herstad, Sandven, \& Ebersberger, 2015), search (Katila \& Ahuja, 2002), collaboration (Tether, 2002), and sourcing (Veugelers \& Cassiman, 2006). The latter three activities are part of Chesbrough's (2003) concept of an open innovation strategy. The most recent contributions to the surging discussion about open innovation discuss broad issues of open innovation such as the emergence of open innovation, the dichotomy of closed and open innovation, the management of open innovation, industrial diversification and IP related issues (Belderbos, Cassiman, Faems, Leten, \& Van Looy, 2014; Colombo, Piva, \& Rossi-Lamastra, 2014; Felin \& Zenger, 2014; Gambardella \& Panico, 2014; Henkel, Schöberl, \& Alexy, 2014; Mina, Bascavusoglu-Moreau, \& Hughes, 2014).

These recent contributions pay tribute to the assumption that an increase in competitiveness drives the implementation of open innovation. That is also highlighted early in the discussion by Chesbrough, who points out that "Competitive advantage now often comes from leveraging the discoveries of others. ... Too much invention and innovation take place outside of your walls to ignore it." (Chesbrough, 2003, p. ii, emphasis added) 
So, open innovation, as innovation in general (Schumpeter, 1942) is targeted towards competitive advantage. Hence, it is reasonable to assume that the competitive environment of a firm affects the firm's value of innovation (Greenhalgh \& Rogers, 2006) and hence influences its propensity to start innovation activities and to implement open innovation practices. We add to the literature about the antecedents of implementing open innovation practices. We pose two hypotheses:

H1: Competition correlates with innovation activities.

H2: Competition correlates with open innovation activities.

\section{Data and Measures}

As indicated above we use the 2013 wave of the BEEPS survey, a firm level survey created by the World Bank and the European Bank for Reconstruction and Development. This survey supplies detailed information on 15884 firms in 30 countries in Eastern Europe and Central Asia (World Bank \& European Bank for Reconstruction and Development, 2015). Recently the dataset has been used for firm level analysis in a number of management related studies (Ayyagari \& Demirg, 2014; Bloom, Schweiger, \& Reenen, 2011; Duvanova, 2014; Kenyon \& Naoi, 2010; Lederman, 2010; Mutluer Kurul \& Tiryaki, 2015). Our analysis focuses on 5,058 firms in the manufacturing industries.

In the analysis we will have two dependent variables. Innovation activities as a binary dependent variable capture firms with positive R\&D expenditure, firms that have introduced a product innovation (goods and services), a process innovation, an organizational innovation, or a marketing innovation in the observation period. The second dependent variable is a metric variable for open innovation constructed from the survey's information. The open innovation variable gives the number of open innovation practices that are employed by the firm: external R\&D spending, external knowledge acquisition, innovation collaboration with domestic partners for product innovation, innovation collaboration with international partners both for product innovation, collaboration with domestic partners for process innovation and collaboration with international partners for process innovation.

The intensity of competition is the log of the number of firms in the industry that can be considered competitors as perceived by the firm's management. We will additionally include the competition as a square term to allow for non-linear effects on innovation and on open innovation.

$R \& D$ intensity captures the sales share spent on $\mathrm{R} \& \mathrm{D}$ activities. The firm's size is the log of the number of employees of the firm. Ownership dummies identify firms with private domestic entities, with private foreign entities and with governmental entities among their owners. The export share captures the firm's involvement in international trade and its exposure to foreign competition. A dummy variable also indicates if firms are part of a larger group of enterprises. The business environment the firm operates in is approximated by a summary measure of the firm's obstacles of doing business. This measure is the mean of the 16 different (binary) variables in the data set that address the obstacles to doing business. We also include a dummy variable indicating whether firms operate in the national capital region. 30 country dummies and 23 sector dummies will capture national and industry effects. Table 1 shows the summary statistics of the sample used in the analysis. 
Table 1. Summary statistics

\begin{tabular}{cccccc|cc|cc}
\hline & All & & & & & \multicolumn{2}{c|}{ Innov=0 } & \multicolumn{2}{c}{ Innov =1 } \\
Variable & & & & & & \multicolumn{2}{c}{$\begin{array}{c}\mathrm{N}=2676 \\
\mathrm{~N}=2382\end{array}$} \\
& $\mathrm{~N}$ & Mean & $\mathrm{SD}$ & Min & Max & Mean & SD & Mean & SD \\
\hline Open Innovation & 2382 & 0.639 & 1.073 & 0 & 7 & & & 0.639 & 1.073 \\
Innovation active & 5058 & 0.471 & 0.499 & 0 & 1 & 0 & 0 & 1 & 0 \\
R\&D intensity & 5058 & 0.068 & 0.251 & 0 & 1 & 0.000 & 0.000 & 0.144 & 0.351 \\
Size & 5058 & 3.243 & 1.284 & 0 & 9.306 & 3.066 & 1.202 & 3.441 & 1.344 \\
Own.: private domestic & 5058 & 0.967 & 0.178 & 0 & 1 & 0.978 & 0.147 & 0.955 & 0.207 \\
Own.: private foreign & 5058 & 0.062 & 0.242 & 0 & 1 & 0.046 & 0.209 & 0.081 & 0.273 \\
Own.: government & 5058 & 0.018 & 0.134 & 0 & 1 & 0.015 & 0.121 & 0.022 & 0.148 \\
Log no of competitors & 5058 & 2.835 & 1.496 & 0 & 4.615 & 3.013 & 1.541 & 2.634 & 1.418 \\
Export share & 5058 & 4.542 & 13.720 & 0 & 100 & 3.991 & 13.551 & 5.161 & 13.883 \\
Part of group & 5058 & 0.091 & 0.287 & 0 & 1 & 0.084 & 0.277 & 0.098 & 0.298 \\
Capital region & 5058 & 0.195 & 0.396 & 0 & 1 & 0.211 & 0.408 & 0.176 & 0.381 \\
Obstacles & 5058 & 0.433 & 0.258 & 0 & 1 & 0.385 & 0.261 & 0.487 & 0.244 \\
\hline
\end{tabular}

Considering the estimation methodology we have to acknowledge that open innovation activities can only be observed with firms that are actually carrying out innovation activities. Estimating the correlation between the independent variables and the open innovation indicator for the whole sample would confuse the firm's decision to innovate and its decision to employ open innovation activities. Estimating open innovation only on innovating firms would also create a bias. Hence, we employ a sample selection model suggested by (Heckman, 1979). It consists of simultaneously estimating two regression models: The first is a probit regression to identify the innovators on all observation (Bahrenberg, Giese, Mevenkamp, \& Nipper, 2008) and the second is a linear regression on the open innovation variable for only the innovating firms (Bahrenberg et al., 2008).

The parameters of the open innovation outcome regression can be interpreted a marginal effects. However, the interpretation of parameters of a probit regression, in particular when second order terms are involved, is not straight forward (Ai \& Norton, 2003).

The probit model can be written as $P(\mathrm{y}=1)=F(u)=\Phi\left(\beta_{1} x_{1}+\beta_{11} x_{1}^{2}+\beta x\right)$. Where $x_{1}$ is the competition variable that is also included as a second order term, $x$ is the matrix of other independent variables and $y$ is the innovation activities variable. The marginal effect of competition on innovation activities is then:

$$
\frac{\partial F(u)}{\partial x_{1}}=\phi\left(\beta_{1} x_{1}+\beta_{11} x_{1}^{2}+\beta x\right) \cdot\left(\beta_{1}+2 \beta_{11} x_{1}\right)
$$

We see that the marginal effect of competition on the innovation activities depends on the level of the competition and on the level of all other variables.

In our analysis we compute the marginal effect for all observations and for various values of competition. The standard errors are computed using the delta method. We graph the average of the marginal effect and the respective confidence bounds in Figure 4 and the corresponding predictions of the propensity to innovate in Figure 3 below.

\section{Findings \& Discussion}

Table 2 displays the parameter estimates of the Heckman selection model, where the selection equation identifies innovators and the outcome regression estimates the correlation of the independent variables with the implementation of open innovation practices for all observations. As a robustness check we estimate the same model for SMEs (smaller than 500 employees) only. The results are structurally identical. Also the parameter estimates do not differ too much. 
Table 2. Parameter estimates of the Heckman selection model

\begin{tabular}{|c|c|c|c|c|}
\hline & & & Only SMEs & employees) \\
\hline & $\begin{array}{c}\text { Open } \\
\text { innovation } \\
\text { b/se }\end{array}$ & $\begin{array}{c}\text { Innovation } \\
\text { activity } \\
\text { b/se }\end{array}$ & $\begin{array}{c}\text { Open } \\
\text { Innovation } \\
\text { b/se }\end{array}$ & $\begin{array}{c}\text { Innovation } \\
\text { activity } \\
\text { b/se }\end{array}$ \\
\hline R\&D intensity & $0.460^{* * * *}$ & & $0.436^{* *}$ & \\
\hline & 0.061 & & 0.0627 & \\
\hline Size & $0.085^{* * *}$ & $0.156^{* * *}$ & $0.084^{* * *}$ & $0.165^{* * *}$ \\
\hline & 0.019 & 0.016 & 0.021 & 0.018 \\
\hline Ownership private domestic & -0.026 & $-0.241^{*}$ & -0.023 & -0.204 \\
\hline & 0.118 & 0.121 & 0.125 & 0.125 \\
\hline Ownership private foreign & $0.375^{* * * *}$ & 0.089 & $0.398^{* * *}$ & 0.075 \\
\hline & 0.092 & 0.091 & 0.098 & 0.096 \\
\hline Ownership governmental & 0.013 & 0.152 & -0.142 & 0.232 \\
\hline & 0.150 & 0.145 & 0.164 & 0.157 \\
\hline Log number of competitors & 0.046 & $0.160^{* *}$ & 0.051 & $0.170^{* *}$ \\
\hline & 0.070 & 0.062 & 0.071 & 0.063 \\
\hline Log umber of competitors ${ }^{2}$ & -0.007 & $-0.045^{* * *}$ & -0.008 & $-0.047^{* * *}$ \\
\hline & 0.012 & 0.011 & 0.012 & 0.011 \\
\hline Export share & -0.000 & $0.005^{* * *}$ & -0.000 & $0.005^{* *}$ \\
\hline & 0.002 & 0.001 & 0.002 & 0.001 \\
\hline Part of group & 0.031 & -0.003 & 0.059 & 0.019 \\
\hline & 0.076 & 0.069 & 0.079 & 0.072 \\
\hline Obstacles & & $0.801^{* * * *}$ & & $0.781^{* * *}$ \\
\hline & & 0.078 & & 0.079 \\
\hline Capital area & -0.014 & -0.073 & -0.008 & -0.080 \\
\hline & 0.063 & 0.055 & 0.064 & 0.055 \\
\hline Constant & -0.648 & -1.296 & -0.663 & -1.341 \\
\hline & 1.059 & 0.921 & 1.054 & 0.922 \\
\hline Sector controls (chi2) & 24.95 & $53.92^{* * * *}$ & 23.52 & $51.89^{* * *}$ \\
\hline Country controls (chi2) & $107.44^{* * * *}$ & $445.59^{* * *}$ & $101.20^{* * *}$ & $440.22^{* * *}$ \\
\hline $\mathrm{N}$ & 2676 & 5058 & 2622 & 4914 \\
\hline 11 & & & & \\
\hline chi2 & & & & \\
\hline $\mathrm{p}$ & & & & \\
\hline
\end{tabular}

Note: Table reports the parameter estimates, standard errors are in italics. $* * *,(* *, *)$ indicate significance at the level of $0.1 \%(1 \%, 5 \%)$.

For the sector control dummies and for the country control dummies we only report a chi2 test for joint significance. It shows that for both samples (all firms and SMEs) the country dummies are jointly significant for both the selection regression on innovation and for the outcome regression on open innovation. The sector dummies, though, are only jointly significant for the selection equation. Essentially this means that once the innovation decision is taken by firms, the sectoral affiliation of firms does not affect the implementation of open innovation practices; the country, however, does. 
The maps displayed in Figure 1 and Figure 2 show the country differences in the propensity to innovate and in the implementation of open innovation practices. The maps show the parameter estimates for the country dummies included in the regressions above. Note, that the reference here is Russia.

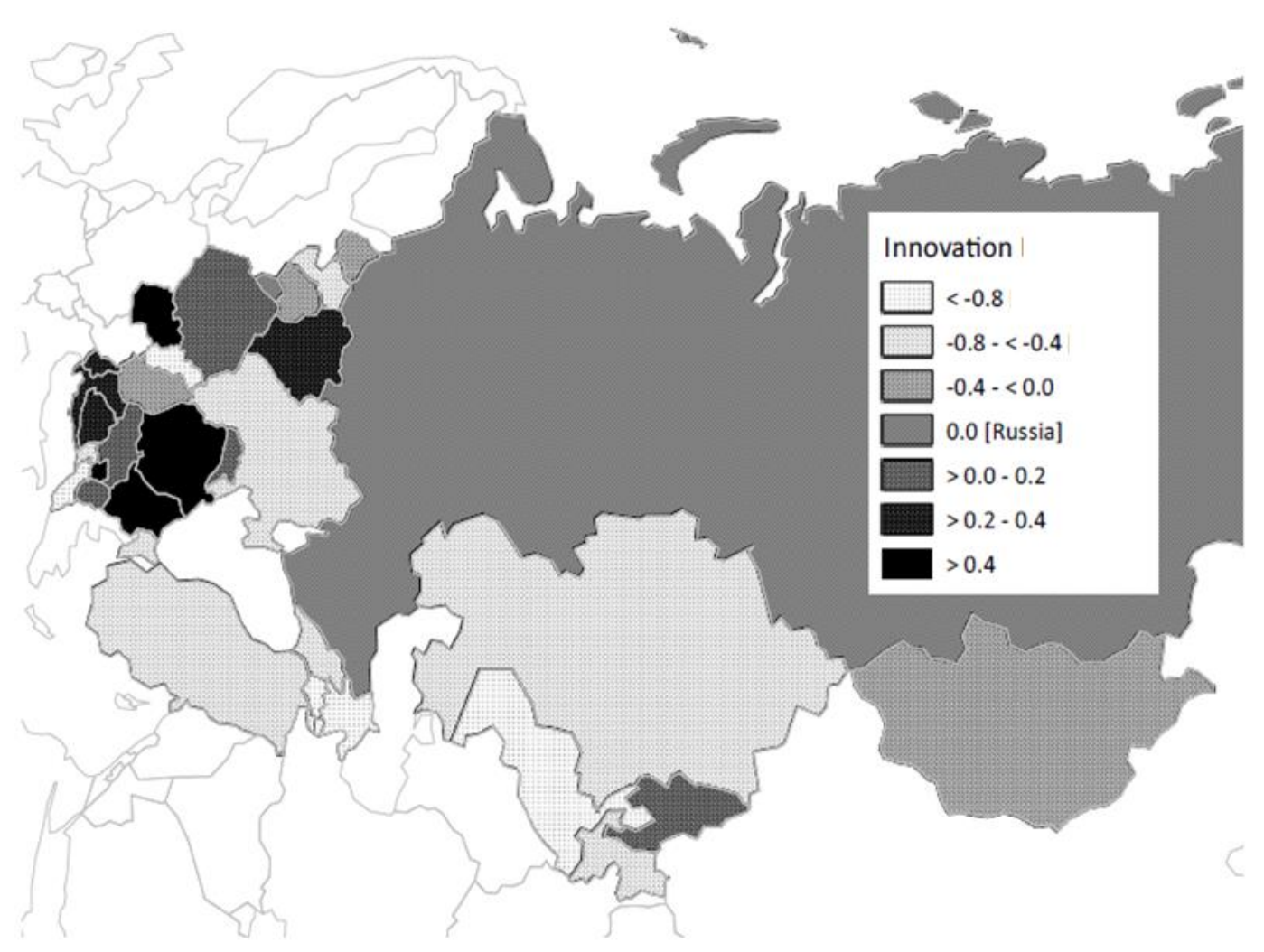

Figure 1. Innovation in Eastern Europe and Central Asia 


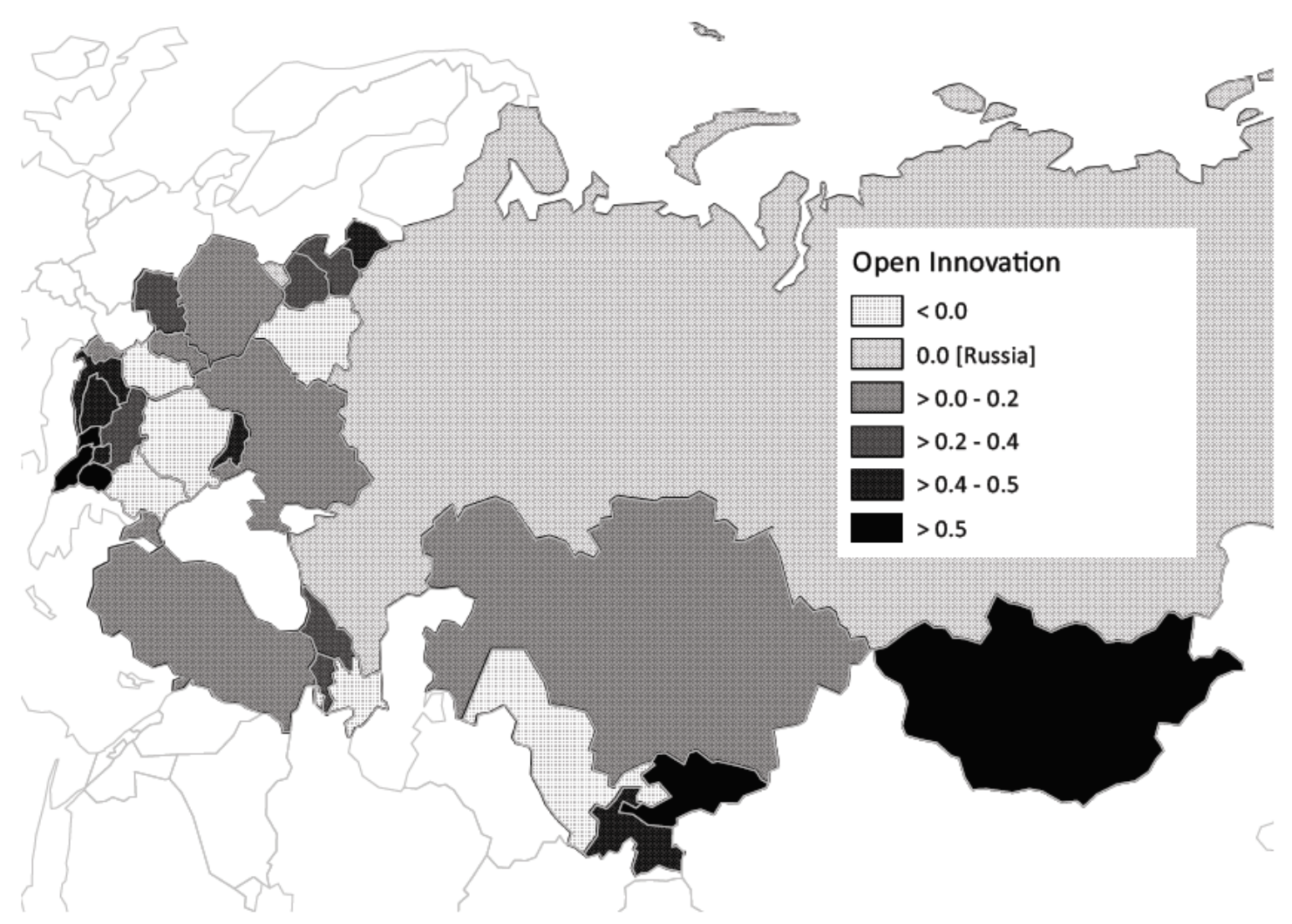

Figure 2. Open innovation in Eastern Europe and Central Asia

When investigating which factors are correlated with innovation activities, we find that size matters as higher size correlates with a higher propensity to innovate. Private domestic ownership correlates negatively with innovation activities.

With relationship to our hypothesis we find that the parameter estimate for the number of competitors is positive significant and for its second order term the parameter estimate is negatively significant. As indicated we have to investigate the marginal effect as derived above. Figure 3 displays the average predicted probability to carry out innovation activities depending on the level of competition. We clearly observe an inverted u-shape. The marginal effects - the first derivative of the prediction - and the confidence bounds are displayed in Figure 4. It shows that there are three broad areas of the marginal effects: Up until a competition of about five competitors we find a significantly positive marginal effect; each increase in competition increases the likelihood of innovation activities. From a level of competition of about ten competitors onward, we find a significantly negative marginal effect. When competition gets too fierce, as approximated by the number of competitors, firms may find themselves in a position where they believe that the returns of innovation efforts cannot be adequately appropriated, hence there is a lack of incentives for innovation and the likelihood of innovation declines. A competition between five or ten competitors does not exert significant effects on innovation activities; in this area innovation we find innovation to be unrelated to competition. 


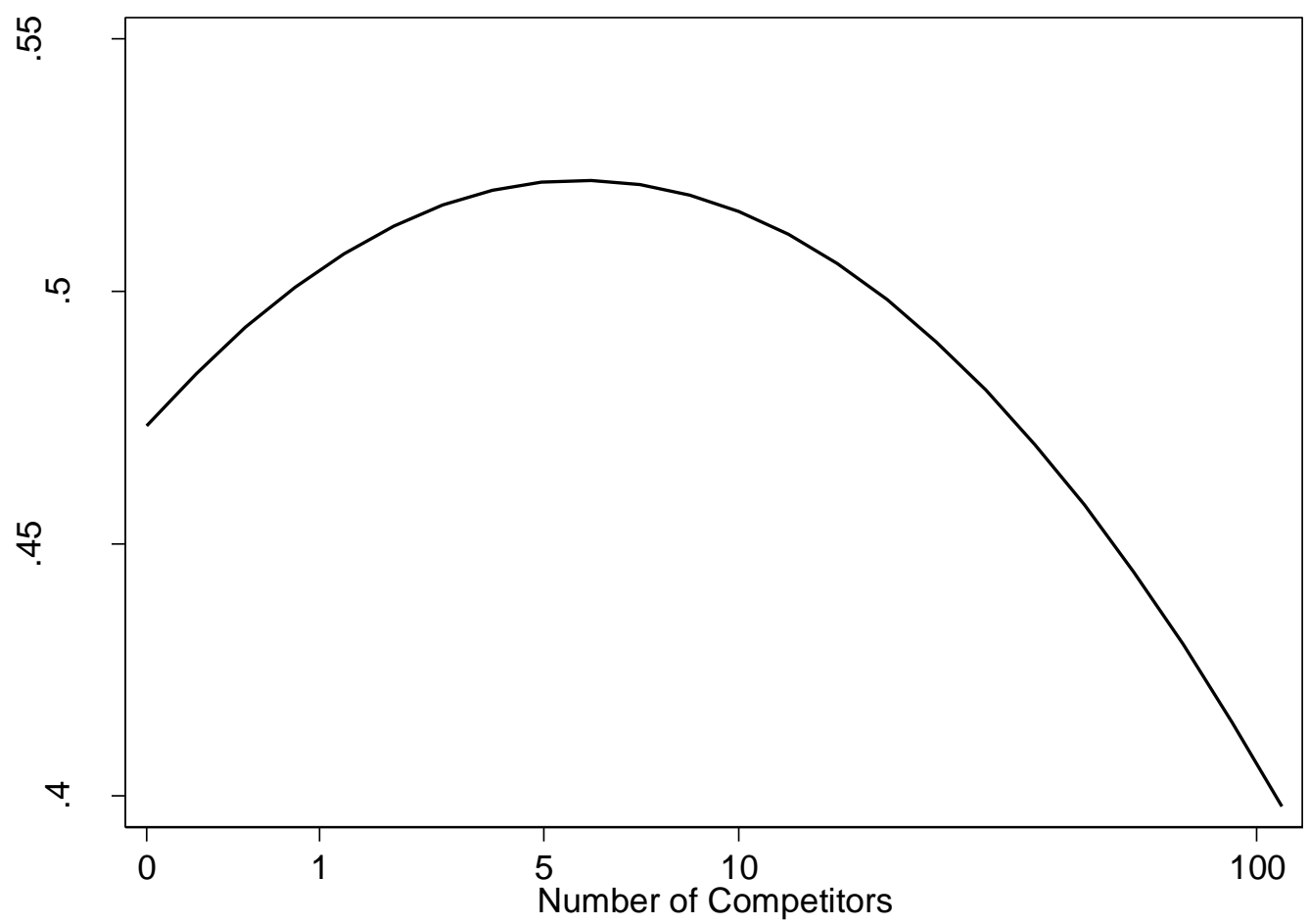

Figure 3. Average predicted probability of innovation depending at different levels of competition

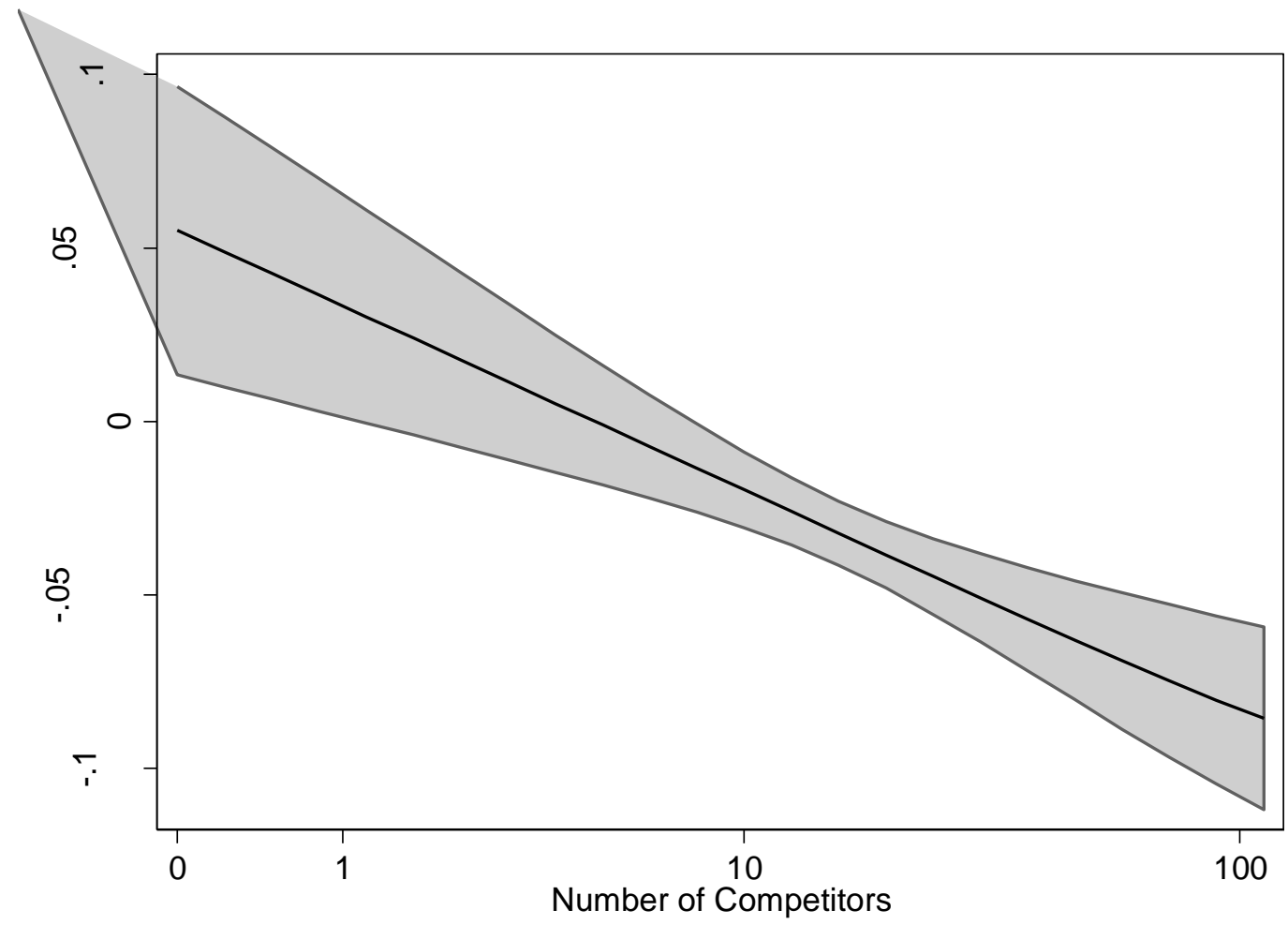

Figure 4. Average marginal effect of competition on the probability to innovate with $95 \%$ confidence bounds

The implementation of open innovation practices as captured by our dependent variable in the outcome regression is correlated with R\&D intensity and with size. The higher the R\&D intensity and the larger the firm the more intense 
is the implementation of open innovation practices. We do not find a significant correlation of competition with the implementation of open innovation practices. This suggests that once the decision to carry out innovation activities is taken, being influenced by competition, the implementation of open innovation practices is unrelated to competition. We observe that the decision to implement open innovation practices is correlated with other firm specific characteristics.

What we however observe is that foreign private ownership correlates positively with the implementation of open innovation practices. This might suggest that the normative nature of open innovation practices (Chesbrough, 2003) is transmitted from abroad What the transmission mechanism is, we can only speculate. It can be the owner's emphasize on increased innovation performance that drives the implementation of open innovation practices. It can be the role model that induces managers in Eastern European and Central Asian firms to implements open innovation. It can also be that the tacit knowledge about the implementation of open innovation practices is transferred through face to face interaction with foreign private owners, who might already have experience in implementing open innovation initiatives. Additional research will be required to elaborate on what are the mechanisms that drive the international dissemination of management practices in general and open innovation practices in particular.

\section{Conclusion}

This paper starts from the insight that innovation has been regarded as the crucial driving force for competitiveness. In terms of innovation management new strategic approaches such as open innovation have continuously been changing the way innovation is carried out at the firm level. Open innovation has emphasized the role of external partners in increasing innovation performance and competitiveness. In this paper we have linked the implementation of open innovation practices to the competitive environment of the firm in Eastern Europe and Central Asia. We find that innovation activities are significantly affected by the competitive environment of the firm. The competitive intensity exerts an inverse u-shaped effect on innovation activities. For the implementation of open innovation practices we do not find significant effects exerted by the competitive environment. Rather, we see that it is international ownership linkages that facilitate the diffusion and implementation of open innovation practices in firms in Eastern Europe and Central Asia.

Of course this research also has some limitations. The first limitation that comes to mind is the focus of the open innovation indicator on inbound and collaborative open innovation practices. Open innovation also encompasses outbound activities (Chesbrough, 2003; Gassmann \& Enkel, 2006) that cannot be captured by the information provided in the survey. Different - potentially - custom tailored surveys are required to provide for these indicators. The dataset used contains cross sectional information. Given this no causal statement can be made as endogeneity is always an issue with cross section datasets. Panel data will be needed to address this point. A more fundamental limitation of this study is concerned with firm level data. Open innovation practices - although having the nimbus of being a strategy - are implemented on a project level. Some innovation project in firms might benefit from open innovation other project will only succeed under a certain degree of closedness. On the firm level these differences tend to be averaged away. More reliable information on the project level would be required to address this issue.

\section{References}

Ai, C., \& Norton, E. C. (2003). Interaction terms in logit and probit models. Economics Letters, 80, 123-129.

Ayyagari, M., \& Demirg, A. (2014). Bribe payments and innovation in developing countries: Are innovating firms disproportionately affected? Journal of Financial and Quantitative Analyis, 49(1), 51-75. http://dx.doi.org/10.1017/S002210901400026X

Bahrenberg, G., Giese, E., Mevenkamp, N., \& Nipper, J. (2008). Statistische Methoden in der Geographie: Band 2 Multivariate Statistik. Stuttgart: Borntraeger.

Baumol, W. J. (2002). The free-market innovation machine. Analyzing the growth Miracle of Capitalism [hardcover]. Princeton: Princeton University Press.

Belderbos, R., Cassiman, B., Faems, D., Leten, B., \& Van Looy, B. (2014). Co-ownership of intellectual property: Exploring the value-appropriation and value-creation implications of co-patenting with different partners. Research Policy, 43(5), 841-852. http://dx.doi.org/10.1016/j.respol.2013.08.013

Blättel-Mink, B., \& Ebner, A. (2009). Innovationssysteme im wissenschaftlichen und gesellschaftlichen Diskurs. In B. Blättel-Mink \& A. Ebner (Eds.), Innovationssysteme: Technologie, Institutionen und die Dynamik der Wettbewerbsfähigkeit (pp. 11-23). Wiesbaden: VS Verlag für Sozialwissenschaften. 
Bloom, N., Schweiger, H., \& Reenen, J. Van. (2011). The land that lean manufacturing forgot? Management practices in transition countries (No. 131). London: EBRD.

Borrás, S., \& Edquist, C. (2013). The choice of innovation policy instruments. Technological Forecasting and Social Change, 80(8), 1513-1522. http://dx.doi.org/10.1016/j.techfore.2013.03.002

Boschma, R., Eriksson, R., \& Lindgren, U. (2009). How does labour mobility affect the performance of plants? The importance of relatedness and geographical proximity. Journal of Economic Geography, 9(2), 169-190. http://dx.doi.org/10.1093/jeg/lbn041

Callon, M. (1992). The dynamics of techno-economic networks. In P. P. Saviotti, R. Coombs, \& V. Walsh (Eds.), Economic and social analysis of technology: Technological change and company strategies (pp. 73-102). London: Academic Press.

Carlsson, B. (Ed.). (1995). Technological systems and economic performance: The case of factory automation. Dordrecht: Kluwer.

Chesbrough, H. (2003). Open Innovation - The new imperative for creating and profiting from technology. Boston, Massachusetts, USA: Harvard Business School Press.

Colombo, M. G., Piva, E., \& Rossi-Lamastra, C. (2014). Open innovation and within-industry diversification in small and medium enterprises: The case of open source software firms. Research Policy, 43(5), 891-902. http://dx.doi.org/10.1016/j.respol.2013.08.015

Cooke, P., Gomez Uranga, M., \& Etxebarria, G. (1997). Regional innovation systems: Institutional and organisational dimensions. Research Policy, 26, 475-491.

Duvanova, D. (2014). Economic regulations, red tape, and bureaucratic corruption in post-communist economies. World Development, 59, 298-312. http://dx.doi.org/10.1016/j.worlddev.2014.01.028

Ebersberger, B., Bloch, C. W., Herstad, S. J., \& Van De Velde, E. (2012). Open innovation practices and their effect on innovation performance. International Journal of Innovation and Technology Management, 9(6), 1-22.

Ebersberger, B., \& Herstad, S. J. (2011). Product innovation and the complementarities of external interfaces. European Management Review, 8(3), 117-135. http://dx.doi.org/10.1111/j.1740-4762.2011.01014.x

Ebersberger, B., Herstad, S. J., Iversen, E., Kirner, E., \& Som, O. (2011). Open innovation in Europe: Effects, determinants and policy. Innovation. Brussels: European Commission, DG Enterprise and Industry. Retrieved from http://www.proinno-europe.eu/sites/default/files/innogrips/Innogrips - WP3_final_0.pdf

Edquist, C. (2005). Systems of innovation - Perspectives and challenges. In J. Fagerberg, D. C. Mowery, \& R. R. Nelson (Eds.), The Oxford handbook of innovation (pp. 181-208). Oxford: Oxford Universtiy Press.

Felin, T., \& Zenger, T. R. (2014). Closed or open innovation? Problem solving and the governance choice. Research Policy, 43(5), 914-925. http://dx.doi.org/10.1016/j.respol.2013.09.006

Freeman, C. (1987). Technology policy and economic performance: Lessons from Japan. London: Pinter. Retrieved from http://www.amazon.com/Technology-Policy-Economic-Performance-Lessons/dp/0861879287

Freeman, C. (1988). Japan: a new national system of innovation. In G. Dosi, C. Freeman, R. R. Nelson, G. Silverberg, \& L. Soete (Eds.), Technical change and economic theory (Vol. 331-348). London: Pinter.

Fritsch, M., \& Slavtchev, V. (2011). Determinants of the efficiency of regional innovation systems. Regional Studies, 45(7), 905-918. http://dx.doi.org/10.1080/00343400802251494

Gambardella, A., \& Panico, C. (2014). On the management of open innovation. Research Policy, 43(5), 903-913. http://dx.doi.org/10.1016/j.respol.2013.12.002

Gassmann, O., \& Enkel, E. (2006). Open Innovation. Die Öffnung des Innovationsprozesses erhöht das Innovationspotenzial. Zfo Wissen, 75(3), 132-138.

Graf, H. (2010). Gatekeepers in regional networks of innovators. Cambridge Journal of Economics, 35(1), 173-198. http://dx.doi.org/10.1093/cje/beq001

Grant, R. M. (1996). Knowledge and the firm: Overview. Strategic Management Journal, 17(Special Issue: Knowledge and the Firm), 5-9.

Greenhalgh, C., \& Rogers, M. (2006). The value of innovation: The interaction of competition, R\&D and IP. Research Policy, 35(4), 562-580. http://dx.doi.org/10.1016/j.respol.2006.02.002 
Grimpe, C., \& Kaiser, U. (2010). Balancing Internal and External Knowledge Acquisition: The Gains and Pains from R\&D Outsourcing. Journal of Management Studies, 47(8), 1483-1509. http://dx.doi.org/10.1111/j.1467-6486.2010.00946.x

Heckman, J. J. (1979). Sample selection bias as a speci cation error. Econometrica, 47(1), 153-161.

Henkel, J., Schöberl, S., \& Alexy, O. (2014). The emergence of openness: How and why firms adopt selective revealing in open innovation. Research Policy, 43(5), 879-890. http://dx.doi.org/10.1016/j.respol.2013.08.014

Herstad, S. J., Sandven, T., \& Ebersberger, B. (2015). Recruitment, knowledge integration and modes of innovation. Research Policy, 44(1), 138-153. http://dx.doi.org/10.1016/j.respol.2014.06.007

Huston, L., \& Sakkab, N. (2006). Connect and Develop. Harvard Business Review, (March), 1-9.

Jensen, M. B., Johnson, B., Lorenz, E., \& Lundvall, B.-A. Å. (2007). Forms of knowledge and modes of innovation. Research Policy, 36(5), 680-693. http://dx.doi.org/10.1016/j.respol.2007.01.006

Katila, R., \& Ahuja, G. (2002). Something old, something new: a longitudinal study of search behaviour and new product introduction. Academy of Management Journal, 45(6), 1183-1194.

Kenyon, T., \& Naoi, M. (2010). Policy Uncertainty in Hybrid Regimes: Evidence From Firm-Level Surveys. Comparative Political Studies, 43(4), 486-510. http://dx.doi.org/10.1177/0010414009355267

Kline, S. J., \& Rosenberg, N. (1986). An overview of innovation. In R. Landau \& N. Rosenberg (Eds.), The positive sum strategy: Harnessing technology for economic growth (pp. 275-305). Washington DC: National Academic Press.

Köhler, C., Sofka, W., \& Grimpe, C. (2012). Selective search, sectoral patterns, and the impact on product innovation performance. Research Policy, 41(8), 1344-1356. http://dx.doi.org/10.1016/j.respol.2012.03.020

Laursen, K., \& Salter, A. (2006). Open for innovation: the role of openness in explaining innovation performance among U.K. manufacturing firms. Strategic Management Journal, 27(2), 131-150. http://dx.doi.org/10.1002/smj.507

Lederman, D. (2010). An international multilevel analysis of product innovation. Journal of International Business Studies, 41(4), 606-619. http://dx.doi.org/10.1057/jibs.2009.30

Leiponen, A., \& Helfat, C. E. (2010). Innovation objectives, knowledge sources, and the benefits of breadth. Strategic Management Journal, 31(2), 224-236. http://dx.doi.org/10.1002/smj.807

Lemola, T. (2002). Convergence of national science and technology policies: the case of Finland. Research Policy, $31,1481-1490$.

Love, J. H., Roper, S., \& Bryson, J. R. (2011). Openness, knowledge, innovation and growth in UK business services. Research Policy, 40(10), 1438-1452. http://dx.doi.org/10.1016/j.respol.2011.05.016

Lundvall, B.-A. (1988). Innovation as an interactive process: from user-supplier interaction to the national system of innovation. In G. Dosi, C. Freeman, R. R. Nelson, G. Silverberg, \& L. Soete (Eds.), Technical change and economic theory (Vol. 349-369). London: Pinter.

Lundvall, B.-A. (1992). National systems of innovation: Towards a theory of innovation and interactive learning. London New York. Pinter.

Malerba, F. (2002). Sectoral systems of innovation and production. Research Policy, 31(2), 247-264. Retrieved from http://www.sciencedirect.com/science/article/pii/s0048733301001391

Mina, A., Bascavusoglu-Moreau, E., \& Hughes, A. (2014). Open service innovation and the firm's search for external knowledge. Research Policy, 43(5), 853-866. http://dx.doi.org/10.1016/j.respol.2013.07.004

Mutluer Kurul, D., \& Tiryaki, S. T. (2015). How credit-constrained are firms in Turkey? A survey-based analysis. Applied Economics Letters, 4851(April), 1-4. http://dx.doi.org/10.1080/13504851.2015.1078439

Nelson, R. R. (1988). National systems of innovation: preface and institutions supporting technical change in the United States. In G. Dosi, C. Freeman, R. R. Nelson, G. Silverberg, \& L. Soete (Eds.), Technical change and economic theory (Vol. 309-239). London: Pinter.

Nelson, R. R. (1993). National innovation systems: A comparative analysis. Oxford: Oxford University Press. Retrieved from http://www.amazon.co.uk/National-Innovation-Systems-Comparative-Analysis/dp/0195076176

Nelson, R. R., \& Winter, S. G. (1982). An evolutionary theory of economic change. Cambridge MA: Belknap Press 
of Harvard University Press.

Nicholls-Nixon, C. L., \& Woo, C. Y. (2003). Technology sourcing and output of established firms in a regime of encompassing technological change. Strategic Management Journal, 24(7), 651-666. http://dx.doi.org/10.1002/smj.329

Peteraf, M. A. (1993). The cornerstones of competitive advantage: A resource-based view. Strategic Janagement Journal, 14(3), 179-191. Retrieved from http://www3.interscience.wiley.com/journal/113455354/abstract

Schumpeter, J. A. (1942). Capitalism, socialism and democracy. London: Unwind.

Tether, B. S. (2002). Who co-operates for innovation, and why - an empirical analysis. Research Policy, 31(6), 947-967. Retrieved from http://linkinghub.elsevier.com/retrieve/pii/S004873330100172X

Vanhaverbeke, W. (2011). The benefits of open innovation in low-tech SMEs: The quilts of denmark story. InnovationManagement, (January), 1-16. Retrieved from www.innovationmanagemenet.se

Veugelers, R., \& Cassiman, B. (2006). In search of complementarity in innovation strategy: internal R\&D adn external knowledge acquisition. Management Science, 52(1), 68-82. http://dx.doi.org/10.1287/mnsc.1050.0470

Wernerfelt, B. (1984). A Resource based view of the firm. Strategic Management Journal, 5(2), 171-180. Retrieved from http://www.ncbi.nlm.nih.gov/pubmed/19064477

World Bank, \& European Bank for Reconstruction and Development. (2015). Business environment and enterprise performance survey (BEEPS). Retrieved from http://ebrd-beeps.com/ 